\title{
Landmarks in Urban Space as Signs
}

\author{
Havva Alkan Bala \\ Faculty of Architecture, Department of Architecture, Konya, Turkey \\ Email: halkanbala@gmail.com
}

How to cite this paper: Bala, H. A. (2016). Landmarks in Urban Space as Signs. Current Urban Studies, 4, 409-429. http://dx.doi.org/10.4236/cus.2016.44027

Received: July 3, 2016

Accepted: October 21, 2016

Published: October 25, 2016

Copyright $\odot 2016$ by author and Scientific Research Publishing Inc. This work is licensed under the Creative Commons Attribution International License (CC BY 4.0).

http://creativecommons.org/licenses/by/4.0/

(c) (i) Open Access

\begin{abstract}
A signal or a symbol has been sent with conscious. Urban space has signified elements like landmark. Landmarks as references signs orient the people. Landmarks are defined as an external point of reference that helps orienting in a familiar or an unfamiliar environment. This study is about to clear out the meaning of landmark for the city users who have perceived reference point with their memory and perception. In other words, this study is about discovering how the city affects the people who experience the urban space within semiotic of landmarks in Konya, Turkey. The method of this study is photo-elicitation to understand how people orient themselves in moving within urban space considering landmarks. Analysis of interview texts, there were six different type of landmarks as; city memory-historical, city landscape/ square, high rise/skyscraper, daily life/city usage, personal memory/personal perception, circulation pattern. In this study the semiology of communication studies codes established by society to produce messages consciously sent and received as signals, signs and symbols.
\end{abstract}

\section{Keywords}

Landmark, Signs, Urban Space, Konya

\section{Introduction}

Landmarks are a kind of signals of urban space. The question is how people orient themselves in urban space considering reference points. People choose the points in the city for their orientation. In the city same natural or man-made elements is seen as signs giving the sense of way finding (Bala Alkan, 2013). In this study landmarks are accepted as a kind of signals, signs and symbols for communication tools. A signal or a symbol has been sent with conscious. In the literature concept of semiology can be categorized in groups. The first group is used semiology as a scientific study of communication system namely signs. The second group used semiology as the study of human 
phenomena. In this study the semiology is used signs as well as human perception. The semiology of meaning works with different phenomena that are not produced purposely as messages (Bala Alkan, 2013). This study tries to discover how landmarks affects people who has a communication with the city. No matter which urban space, there is two alternative sender as urban community or administrative authority (Mounin et al., 1980). The semiology of meaning works with different phenomena that are not produced purposely as messages. The architect building as a structure is not doing so to send a message to the society that will use it. The building is the part of city and defining urban space quality (Bala Alkan, 2013).

This study is not about the physical or technical structure of the city. This study is also not about the social, economic, administrational, cultural aspects of the city or about urbanism dealing with sociology of urban space. The aim of this study is to understand city users perceive reference point in urban space. The method of this study is photo-elicitation to understand how people orient themselves in moving within urban space discovering how the city affects the people who experience the urban space within semiotic of landmarks in Konya, Turkey.

\section{Method}

In this research all information from the city user has been supplied with camera, video recording, voice recording and interviewing with photo elicitation. Photo elicitation methodology has used photography and at the same time tape recorder. Photo elicitation techniques involve using photographs or film as part of the interview (www.visualsociology.org.uk). In this case the images can be taken special by the researcher with the idea of using them to elicit information. Typically, the interviewee's comments or analysis of the visual material is itself recorded, either on audio tape or video, etc. In their articles Kalin and Yilmaz (2012) refer landmark perception studies and claimed that:

"In recent years, visual perspectives of vehicle drivers, road traffic and pedestrians and the role of landmarks in way finding and navigation studies are the most important two topics appearing as central concerns of urban studies related with visual experience of cities."(Kalin \& Yilmaz, 2012).

The studies about landmark for aesthetic perspectives of vehicle drivers contains different field like visual experience, the perception of road traffic not only motor vehicle but also cyclist and pedestrian (Froment \& Damon, 2006; Foltête \& Prombini, 2007; Merriman, 2004; Nikolov, 2008; Robertson, 2007; Taylor, 2003; Zacharias, 2001). The other group of studies about landmark is for spatial ability in way finding (Cornell, Heth, \& Skoczylas, 1999; Cubukcu \& Nasar, 2005; Rossano, West, Robertson, Wayne, \& Chase, 1999; Roger, Bonnardel, \& Le Bigot, 2009), The ontology of landmark from various points like creating extensive spatial ability in way finding (Murrieta-Cid, Parra, \& Devy, 2002; May \& Ross, 2006; Peebles, Davies, \& Mora, 2007), the value in helping orientation and navigation (Herzog \& Leverich, 2003; Herzog \& Kropscott, 2004; Klip- 
pel \& Winter, 2005; Omer \& Goldblatt, 2007; Caduff \& Timpf, 2008).

The method of this study is photo-elicitation to understand how people orient themselves in moving within urban space considering landmarks. Thirty participants took photographs of city centre of Konya and interviewed while viewing their photographs. Analysis of interview texts focused on meaning of environment that connected participants to their life style, their perception and were organized three overlapping themes:

- signaling the city,

- confirmation of the route,

- personal perception, memories of the built-up environment.

\section{Symbolism, Semiology and Urban Space}

Symbols are commonly applied to formal iconographic representations. Symbolism encompasses complex conceptual codes and pictorial representations of a worldview that operates in multiple levels and scales. They frequently take the form of images, words, sounds or gestures, and are used to express beliefs, thoughts and theories. Urban symbolism is commonly associated with the enhancement of formal urban figures, objects or pieces of collection and landmarks (Zappulla et al., 2014). Psychologist and philosopher Erich Fromm defined three major types of symbols: the conventional, the accidental and the universal, stating that only the latter two bear the features of symbolic language. The fundamental system of sign types-of an icon, index and symbolinvented by philosopher and logician Charles Sanders Peirce is known and most broadly applied in the semiotic practice. Regardless of separate attempts to absorb them, the discourse of architectural theory has no strict classification, and the term of symbolism often encompasses icons, metaphors, ideograms and associations (Mankus, 2014). Semiotic is a language to talk about signs. Human civilization is dependent upon signs and systems of signs, and human mind is inseparable from the functioning of signs (Morris, 1964). Everything is a sign, or a code. The semiotic system can define the decoder and encoder. Mostly we are a decoder in daily life. It is difficult to being an encoder in pass. Signifier, signified and signs creates a communication. Morris (1964) defines semiotics the interrelationship between the message itself and the recipient of that message (Figure 1).

The sources of semiology based on two groups:

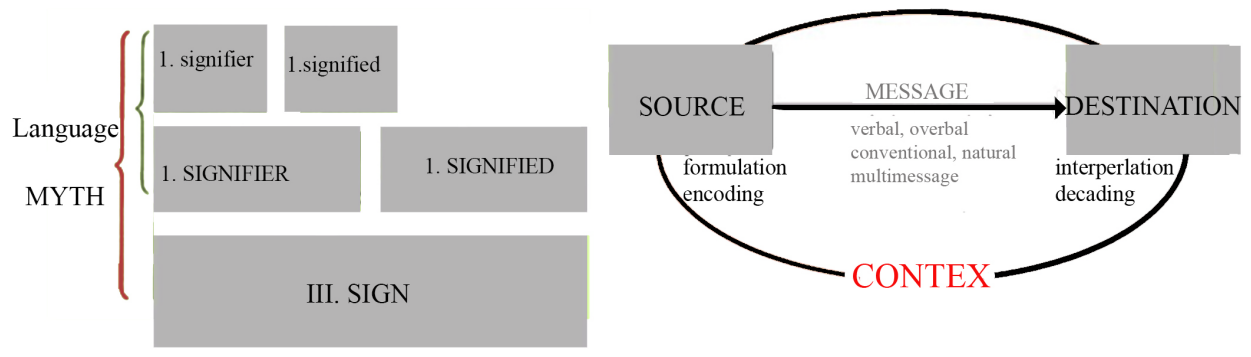

Figure 1. Semiotic is a language to talk about signs. 
1) The first group is de Saussure (1966) approach of linguistic work. De Saussure (1966) defines a sign as the signifier and the signified which cannot be separated.

2) The second group the philosophical work of Peirce (1958). Peirce (1958) defines theory of the signs based upon represent, object and interpreting.

According to Günay (2015), Derrida (1978) argues, the writer of the message ceases to have any significance once the message has been written, as interpretation is entirely determined by this interplay between the message and its recipient. Heidegger (1977: pp. 134-135) explains the modern age as "the conquest of the world as picture", and the picture has gained a new meaning that he calls 'structured image', through which "man brings into play his unlimited power for the calculating, planning, and molding of all things". It is also true that each historical age has its own concept of greatness, but for Heidegger (1977: p. 135) when we are talking about the gigantic, "everywhere and in most varied forms and disguises the gigantic is making its appearance". Before explaining the city case we should clarify the concept of object, sign, image, symbol and meaning relation.

Semiotics has been defined simply as the study of signs (Guiraud, 1975). A sign of an object may simply turn the interpreter of the sign upon the object while at the other extreme it would allow the interpreter to take account of all characteristics of object in question in the absence of the object itself. A simple red apple can be symbolizing the human mankind adventure starting from the "sin" with Eva and Adam, or being an “invention" by falling Newton's head or communication-information-technology age. Signs, symbols have the potential of creating new meaning and image (Figure 2).

In study of signs sometimes the meaning is not so universal but changes according to culture and human experience including geography, history, perception and memories (Kravchenko, 2006). Semiotic is the science use of special signs to state facts about signs. Actually semiotic is a language to talk about signs. If you say an American citizen what "the women in red" reminds to him/her probably they will talk about the comedy film directed by Gene Wilder in 1984, On the other hand the same expression will remind a Turkish citizen may talk about protests in Istanbul, May 28, 2013 in Gezi Park (Figure 3). The woman in red has turned as the policeman showers her in pepper spray at close range become an icon. These images of a Turkish riot policeman using tear gas against a woman in Taksim Square, as people demonstrate against the destruction of trees in Gezi Park, became an iconic photograph for the protests in Istanbul, May 28, 2013.
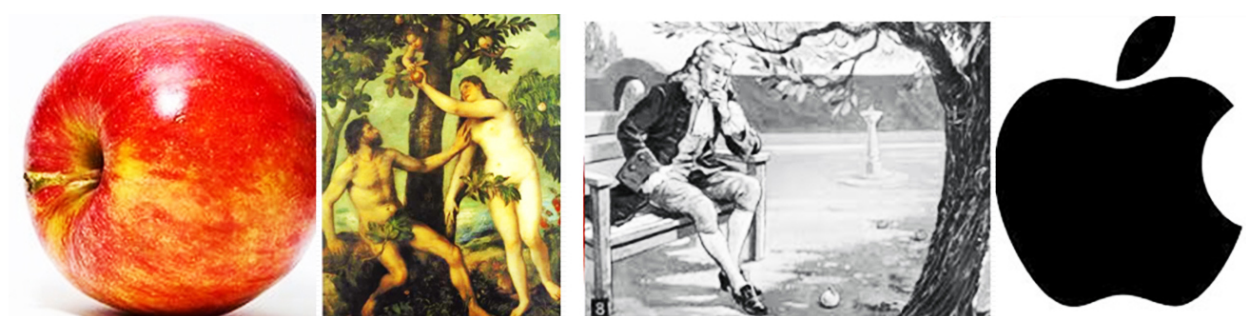

Figure 2. Object, sign, image, symbol and meaning relation. 
A sign of an object may simply turn the interpreter of the sign upon the object while at the other extreme it would allow the interpreter to take account of all characteristics of object in question in the absence of the object itself (Kravchenko, 2006). An object or an event can change a sign or symbol having wider meaning. Morris (1964) defines semiotics as a science among the sciences and an instrument of the sciences. Linguistics, logic, mathematics, rhetoric and aesthetics have been the foundation of sciences. We should try and understand the play of signs and get the semantic approach of city structure (Barthes, 1967). Cities are the manifestation of symbolic worldviews and realities. Symbols, signs and codes are treated in the text as visual figures revealing some concept, events, ideas and sometimes they turn into traditional or universal meaning (Mankus, 2014) (Figure 4).

It is very easy metaphorically to speak of the language of the city as we speak of the language of the cinema or the language of flowers. Barthes' (1967) writing-particularly in the essay "Semiology and the Urban" in which Barthes considers the "possibility of a semiotics of the city", the city is a discourse and this discourse is truly a language:

- the city speaks to its inhabitants,

- we speak our city,

- the city where simply by living in.

Sometimes we cannot recognize the city when the perception changes. The same city represent and being as it is but the way of presentation of it totally defines different images. How to pass from metaphor to analysis when we speak of the language of the city? (Figure 5)
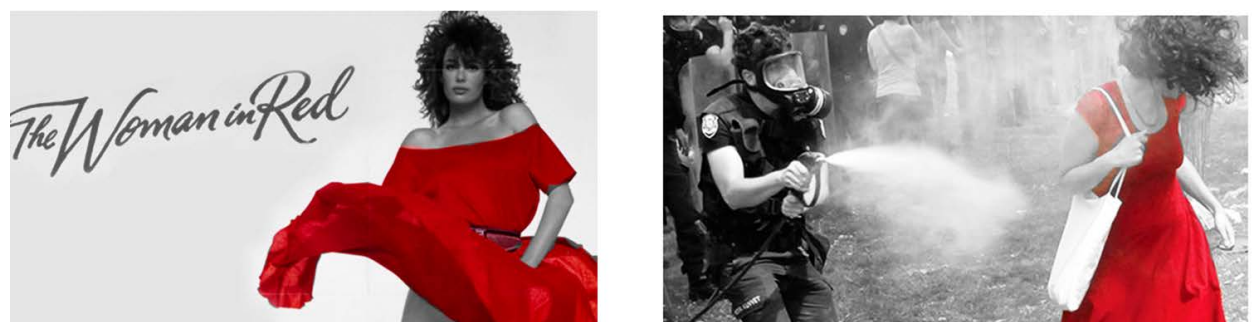

Figure 3. Images sometimes get the meaning according to culture like in case "The Women in Red".
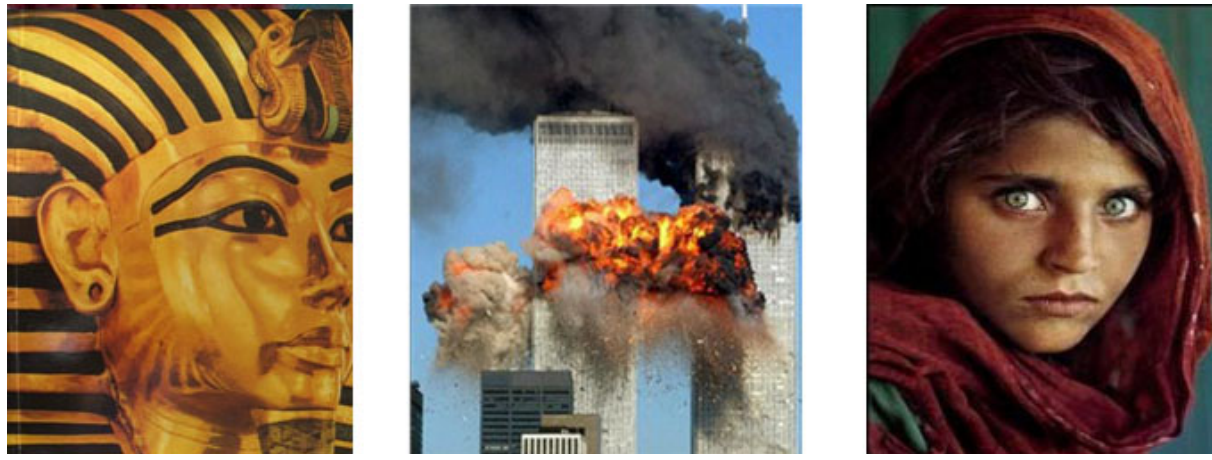

Figure 4. Symbols, signs, codes, events are treated as traditional or universal meaning. 


\subsection{Landmarks}

Landmark can be a good sign for urban spaces in the cities. Landmark as a word is used in different fields with referring different concept. Linguists as well as urban planners defines landmark anything that is easily recognizable. Landmarks generally have defined a country, a culture or a period in the history (Figure 6).

Landmarks are defined as an external point of reference that helps orienting in familiar in a familiar or unfamiliar environment (Heth et al., 1997). Landmarks as external cues play an important role to maintain orientation. Two ways that landmarks are used seem fundamental. Of all the events encountered along a path, the way finder has to select cues that can be associated with locations, bearings, or behavioral contingencies (Jansen-Osmann \& Wiedenbauer, 2004; Presson \& Montello, 1988). In that aspect landmarks have important roles in the city. Humans acquire spatial knowledge of a new environmental space-a space, which is not perceivable from one single vantage point-by travelling through this environment (Appleyard, 1966). This way finding ability can be accomplished through a variety of means, for example cue based piloting, path integration, navigation by cognitive maps (Newcombe \& Huttenlocher, 2000) or by guidance instruments like a compass and materials like photos or verbal descriptions (Golledge, 1997). Humans may also use tactile cues to orientate themselves (Loomis, Klatzky, Golledge, Cicinelli, Pellegrion, \& Fry, 1993).
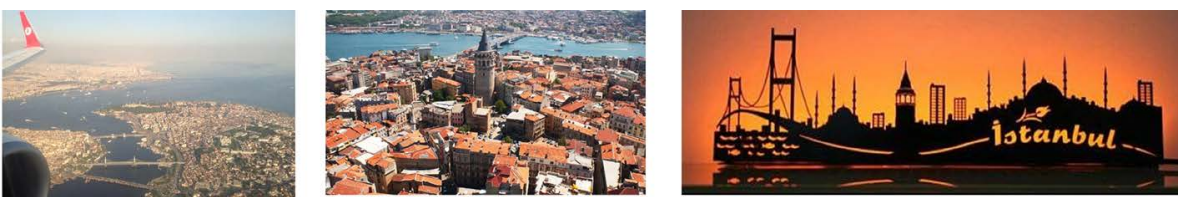

Figure 5. How to pass from metaphor to analysis when we speak of the language of the city?
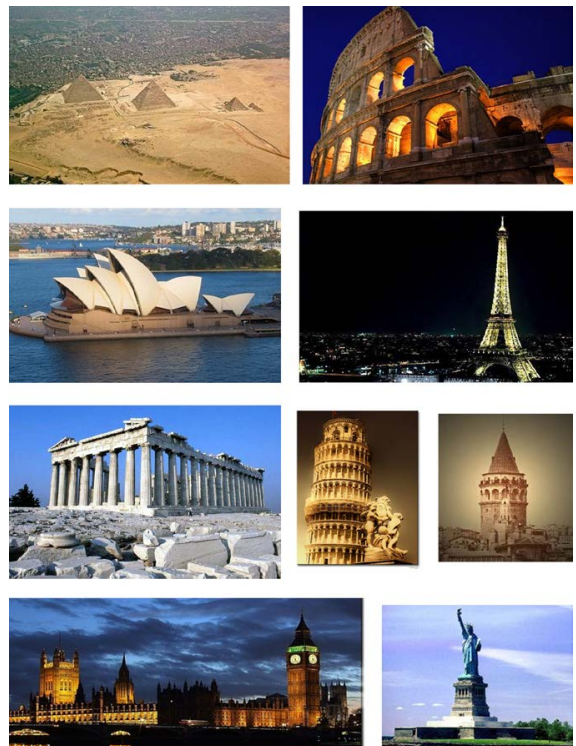

Figure 6. Landmarks generally have defined a country, a culture or a period in the history. 
Kevin Lynch (1960) is one of the well-known researchers who define landmarks as the point references considered to be external to the observer (Osborne, 2001). According to Lynch (1960) landmarks are simple physical elements which may vary widely in scale. Lynch (1960) in his book also emphasizes on the point mentioned below;

- landmarks become more easily identifiable.

- landmarks generally chosen as significant.

- landmarks are familiar to the citizens, guideless to the citizens,

- physical characteristic of landmarks based on singularity, uniqueness and memorable in the context.

- subjects might single out of landmarks for their cleanliness in a dirty city, newness in an old city, greatness of size.

- making the elements visible from many locations.

- setting up a local contrast with nearby elements i.e. variation in setback and height.

- location at a junction involving path decisions strengthens a landmark.

- the activity associated with an element may also make it a landmark.

- people who used distant landmarks did so only for very general directional orientation or more frequently in symbolic ways.

- landmarks may be isolated, single events without reinforcement.

- a sequential series of landmarks, in which one detail calls up anticipation of the next and key details trigger specific moves of the observer, appeared to be a standard way in which these people traveled through the city (Kuipers, 1982).

\subsection{The Function of Landmarks}

Landmarks may be defined in a number of ways, whereby one can differentiate between landmarks as an organizing concept and as navigation aids (Golledge, 1991): As an organizing concept landmarks may serve as a reference point that determines the localization of other points in the environment (Sadalla, Burroughs, \& Staplin, 1980), or serves as a prototype location (Newcombe \& Huttenlocher, 2000). Landmarks as visual objects, which are perceived and remembered because of their shape and structure (Presson \& Montello, 1988) or their socio cultural significance (Appleyard, 1969) may help to find the way around. Denis (1997) describes the following key functions of landmarks:

1) Signaling sites,

2) Help for the location of other landmarks and,

3) Confirmation of the route followed.

In an early study, Lynch (1960) classified and marks into strategic and thematic nodes, paths, boundaries, and districts, and identified them as one key entity for people to get around in their environment. Further studies showed very well that landmarks affect the spatial representation and the acquisition of route- and survey knowledge (Beck \& Wood, 1976; Carr \& Schissler, 1969; Jansen-Osmann \& Wiedenbauer, 2004).

This study is to discover how the city affects the person who experiences it considering 
landmarks. There are several ways to communicate citizen and landmarks are one of them. In this paper the relation between semiology of landmarks and urban space based on Konya, Turkey.

\subsection{Landmarks in Konya}

Konya is one of the oldest settlements in the centre of Middle Anatolia as a crossroads of different culture and rich space (Figure 7).

Konya is well-known in international milieu with Çatalhöyük settled beyond BC. 7000. Konya can be called an international landmark itself. Konya is special city considering city image and community identity. Although Konya has Mevlana Celaleddin Rumi well-known thinker all over the world the city is not known its real properties. In Konya there are important places like Sille where different civilizations met or Kilistra, the place of first Christians and Rumi the symbol of tolerance.

The Period of Anatolian Seljuk was the resplendent years of Konya considering social, political and spatial aspects. This resplendent condition is seen in every aspect since Konya was the capital city of Anatolian Seljuk managed by Alaeddin Keykubat sensitive to art, science and variety of ideas. After Alaeddin Keykubat called Mevlana and his father to Konya, the attractiveness of the city increased. Popular artist, scientist and philosophers moved to Konya in that period (Figure 8).

The invitation of Mevlana to human being affects the social and spatial character of the city. After Mevlana settled Konya city enlarged from city wall. Quarters and streets

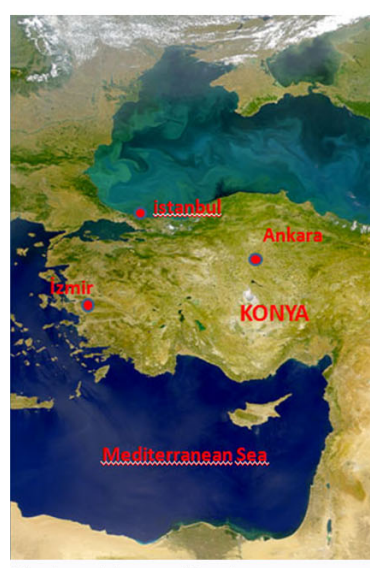

Mevlana Museum/Tomb Sultan Selim Mosque

Karatay Museum/Medrasa

İnce Minare Museum/ Medrasa

Aziziye Mosque

Alaeddin Hill

Anit Square

Fair

Nene Hatun Park

Dedeman Hotel

Rixos Hotel

Kule Site

Zafer Square

Revenue and Municipality Building

Bus Terminal
Konya can be called an international landmark itself.

Konya is the capital of Ancient SELÇUK'S

KONYA, the land of MEVLANA CELALEDDIN RUMI

Figure 7. The location of case study. 
closed to outside, unrestricted pattern and integrity with rich interior architectural properties were formed in the outside of the city wall. Konya becomes a social center and place of pilgrimage with commercial function after Mevlana died. Konya got a large amount of masterpieces which reflect the understanding of Seljuk's system, architectural styles, their art and aesthetic value in that period (Figure 9).

In the Middle Age and terms following of Middle Age the characteristics of the city is interior castle surrounded by Alaeddin Hill and streets formed as ray of beam to Hill. Alaeddin Hill and Mevlana Museum was the first social, commercial and spatial centre. Today buildings belong to that period have been stand on. At the end of the 19th century population increased, rapid urban development enlarged the city boundary to fair
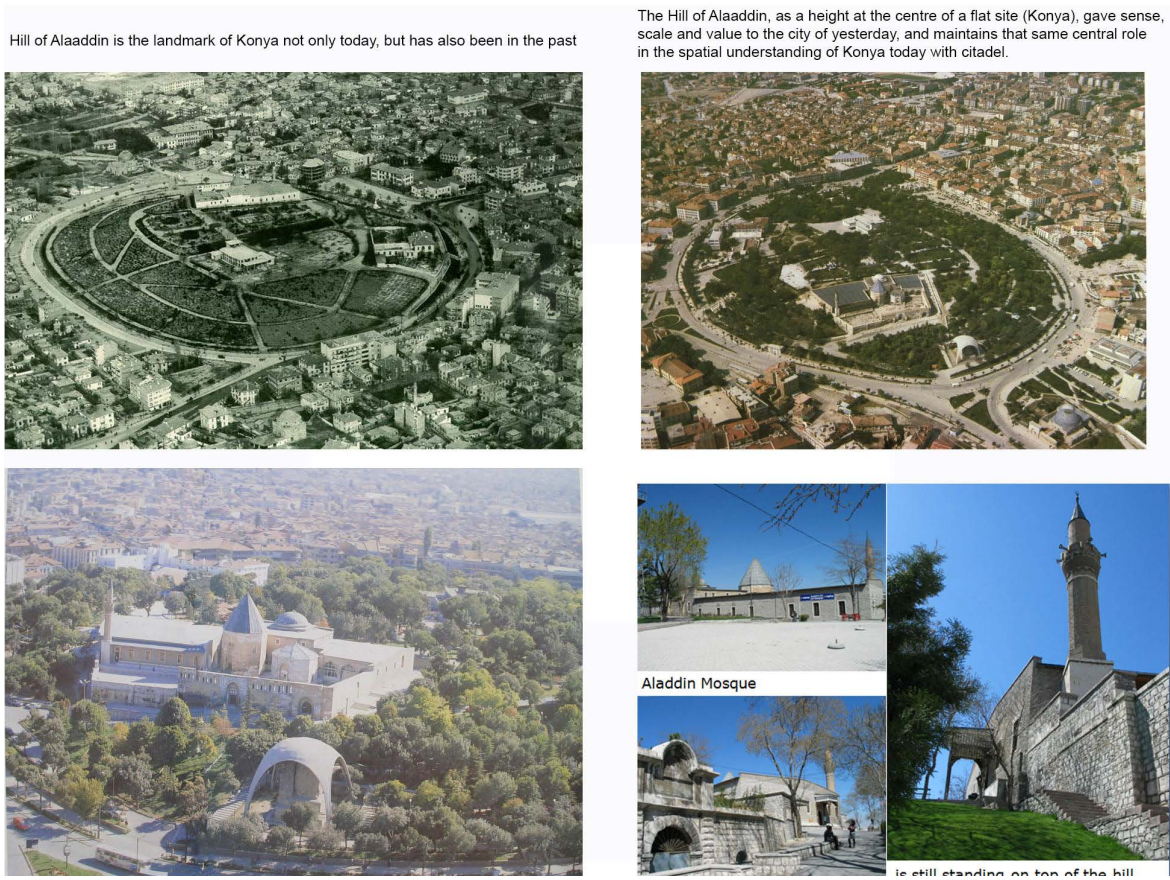

Figure 8. The first settlement and landmark of Konya: Alaeddin Hill.
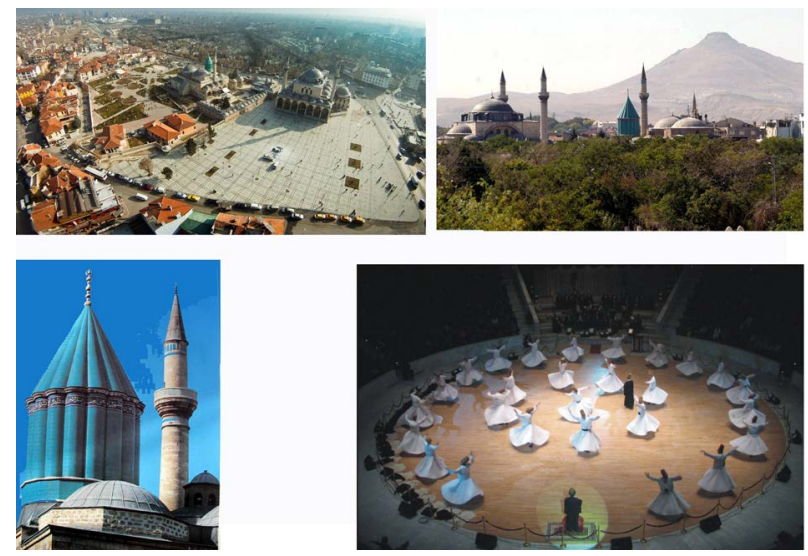

Figure 9. Mevlana Celaleddin Rumi and Sufism is an important phenomenon of Konya. 
and its environment. Mevlana and its environment becomes historical city center. Population, the trade capacity and social changes creates new spaces and buildings. Capitalism, competition and new social values defined construction sector. Skyscraper, high-rise buildings racing against historical city are constructed and bring new architectural understanding. In this paper architectural products in past and in today will be examined considering landmarks. Konya has a flat geographic property. Thus all mankind elements could be perceived easily. The old historical buildings, landscape elements and especially high-rise buildings are signaling sites, help for the location and confirmation of the route followed (Figure 10).

Konya is an ancient city and the capital of Anatolian Seljuks. Konya is growing rapidly, becoming more crowded, high-rise buildings especially hotels, office buildings have been constructed nowadays. However, regarding the historical background of the city, these tall buildings can be called bewildered landmark challenging the ancient Konya (Figure 11).

When we have checked old post cards, calendars and stamps we can call that Konya is a landmark as itself with Mevlana Celaleddin Rumi and Anatolian Seljuk's masterpieces as Karatay Madrasah and İnceminare Madrasah from the 12th century (Figure 12).
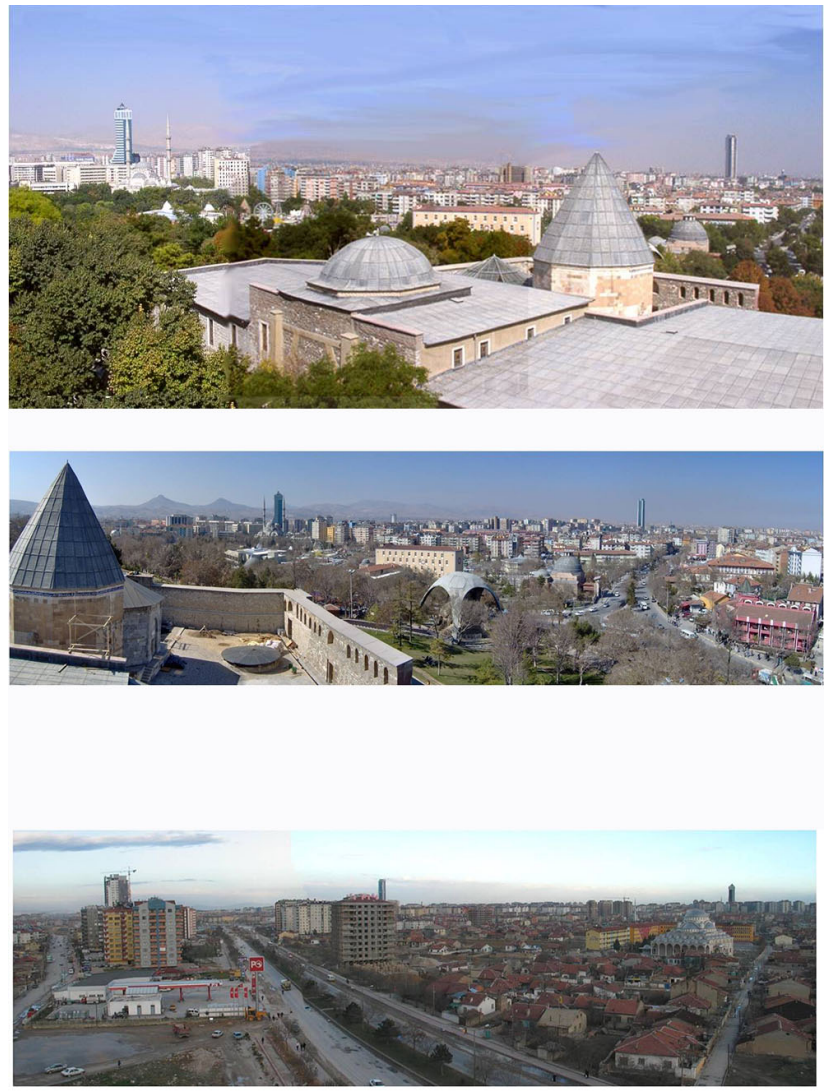

Figure 10. Tall buildings as new landmarks has competition with traditional historical landmarks in Konya. 
There are about 25 Seljuk buildings with portal remaining in Anatolia. Some of the most well-known and beautiful Ancient Seljuks portal is in Konya. One of them is Karatay Medresse. Karatay Medresse, constructed in 1251, stands to the north of this hill, and now is a museum which holds the best examples of Seljuk tiles and ceramics. İnce Minare Medresse like Karatay Madresse is among Konya's finest and most impressive Seljuk Turkish architectural masterpieces. The Ince Minare Medresse is located on the west side of the Alaeddin Hill near the Great Karatay Medresse. It's grand portal, heavily and completely carved with Seljuk decoration and Kur'anic inscriptions, is among the finest of all Seljuk grand portals. As in the past Karatay and Ince Minare Medresse is landmark of Konya (Figure 13).
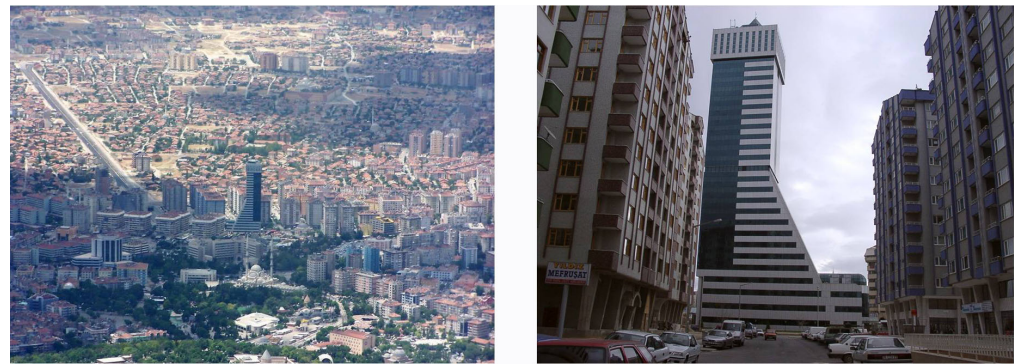

Figure 11. Bewildered landmark challenging the ancient city.
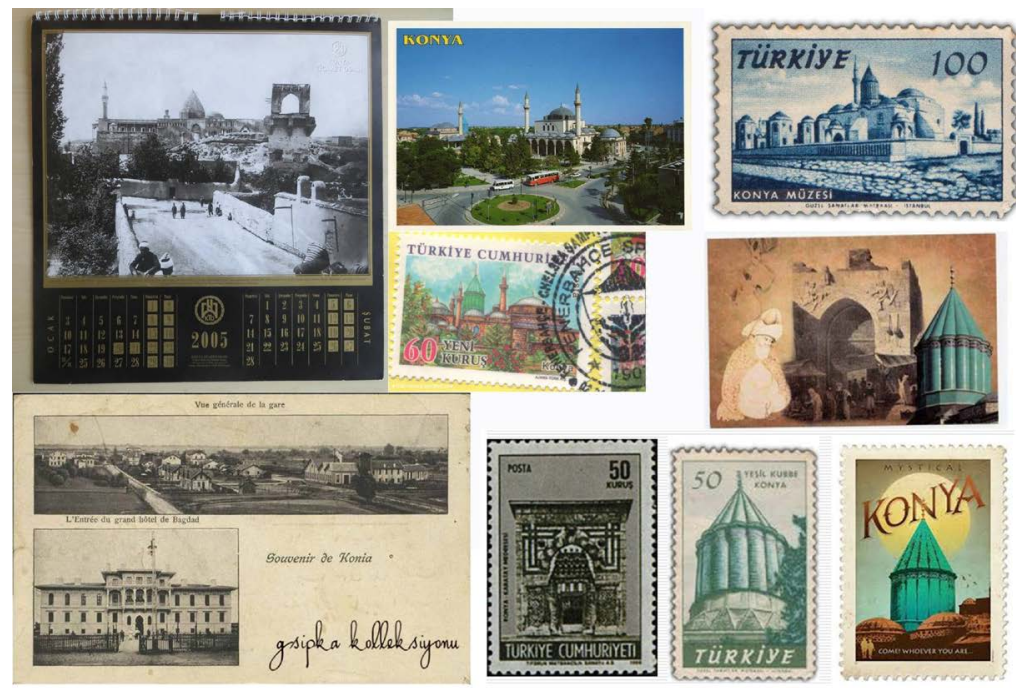

Figure 12. Old post cards, calendars and stamps give clues about landmark.
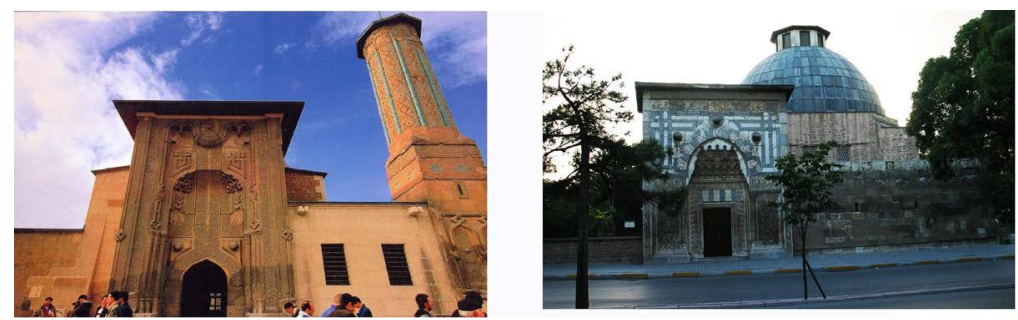

Figure 13. İnceminare and Karatay Medresse. 


\subsection{Semiotic of Landmarks in Konya with Photo-Elicitation}

The method of this study is photo-elicitation to understand how people orient themselves in moving within urban space considering landmarks (Stewart, Liebert, \& Larkin 2004). Thirty participants took photographs of city centre of Konya and interviewed while viewing their photographs. Analysis of interview texts focused on meaning of environment that connected participants to their life style, their perception. Participants were ten architectural students from Selçuk University, ten tourists around the Mevlana Museum, the most well-known part of the city, ten city dwellers living in Konya at least twenty years. The primary method of the study is to contact with volunteers to take photography according to our comment. A follow-up letter was sent to recruits reiterating instructions on their role as a study participant:

"With your camera, take pictures of places that are important to help your orientation. Focus on the physical elements which are reference point of you while walking or driving. This item may be a huge building or very small sidewalk. The only thing you should be carefully while deciding these chosen photos should give an answer one of three questions mentioned below,

- How you recognize that you are in Konya?

- Where do you meet in Konya?

- What is your reference point while going from one place to another?

It is not expected that your places will be the same as another person's places. The places you choose to take pictures could be as "simple" as your backyard, the neighborhood park, the diner in town, your mosque, or whatever place has been meaningful for you. The places you take pictures could be related to this three questions. After you are finished taking pictures, send the camera back to us. We will schedule a time to talk about your special places. After selecting ten photos, we need your description, feeling, reason to about that selection. During our follow-up discussion, we will ask about the places in your pictures and their importance to you. Thank you for your support."

We did not put any limitation for defining where the boundaries of Konya as a city. We asked each participant to take 10 photos according to our question. Each participant was coupled with long interviews, referred to as photo-elicitation. We asked participants to take pictures of reference points of Konya according to them. We did not make any explanation or definition about landmarks. Students, tourists and city dwellers took pictures and then write description of that picture. From their analysis, we able to identify places sign. Six different groups of landmarks are defined as;

- Landmark as City Memory-Historical,

- Landmark as City Landscape/Square,

- Landmark as High Rise/Skyscraper,

- Landmark as Daily Life/City Usage,

- Landmark as Personal Memory/Personal Perception,

- Landmark as Circulation Pattern,

The detail of this classification is seen in Table 1, Table 2 and Table 3. 
Table 1. The classification of landmark according to photo-elicitation.

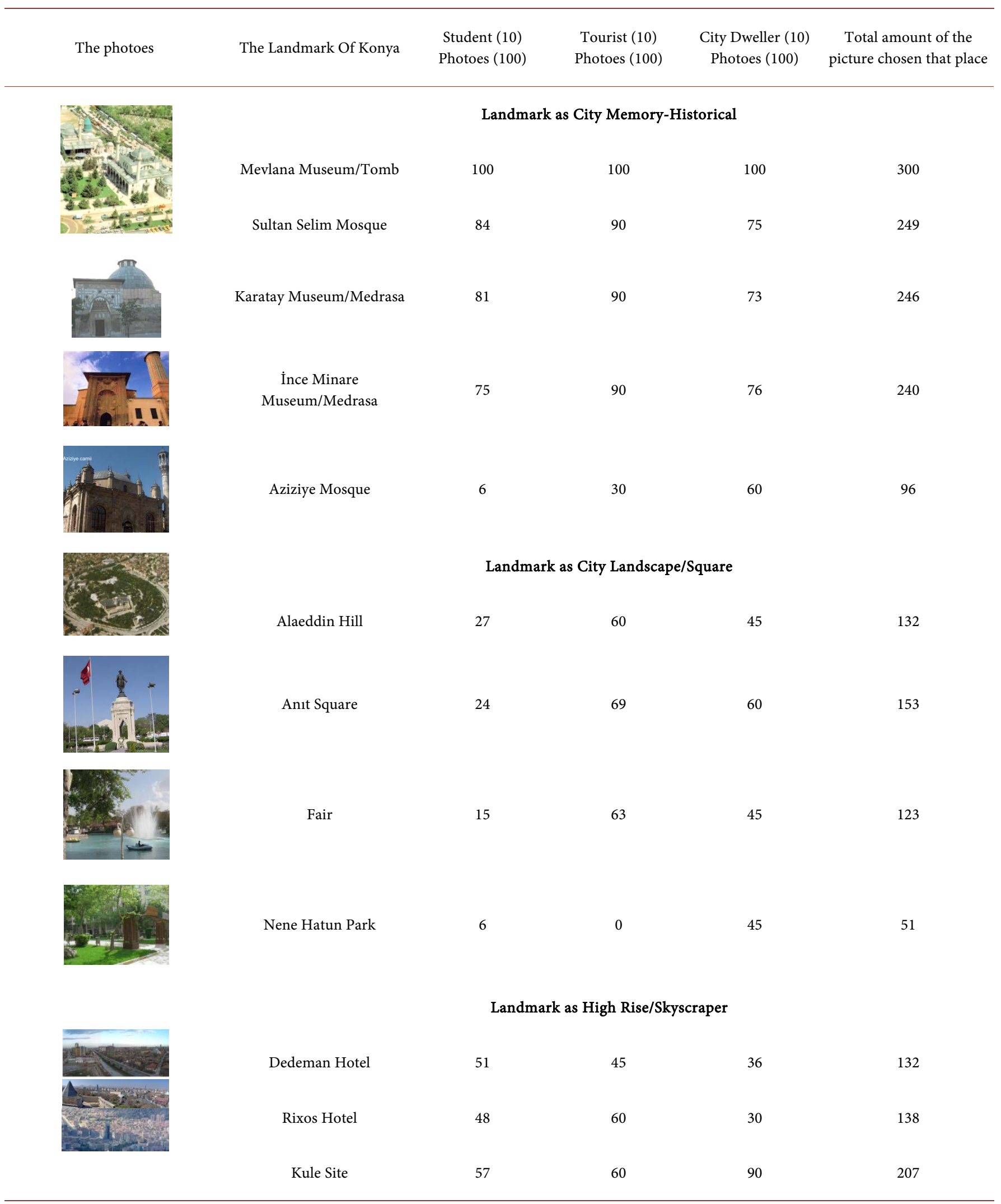




\section{Continued}

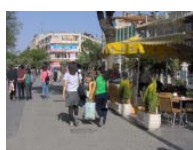

Landmark as Daily Life/City Usage

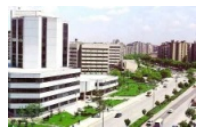

Zafer Square

78

75

75

228

Municipality Building

20

5

80

105

Mc Donalds

25

27

67

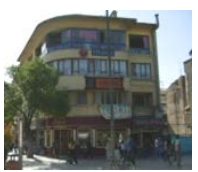

Kibrit Corner

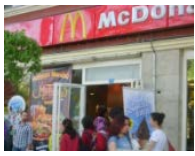

Bus Terminal

69

75

72

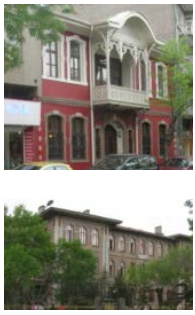

Chamber of Architecture

30

0

0

30

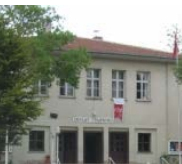

Konya High School

18

39

9

66

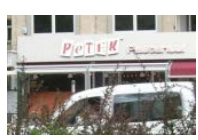

Theatre Building

6

3

21

30

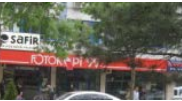

9

9

18

Copy center 99

57

0

57

Landmark as Circulation Pattern

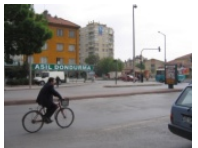

Beș Yol (Assl IceCream)

15

0

42

57

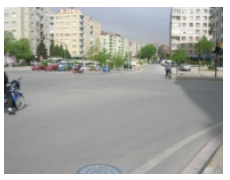

Sille Subway

0

51

60 
Table 2. The ratio of symbolic power of landmark according different perception.

\begin{tabular}{|c|c|c|c|c|c|}
\hline The Landmark of Konya & Order & $\begin{array}{l}\text { Ratio of landmark for } \\
\text { the Student } \%\end{array}$ & $\begin{array}{c}\text { Ratio of landmarks for } \\
\text { the tourist } \%\end{array}$ & $\begin{array}{l}\text { Ratio of landmarks for } \\
\text { the City Dweller\% }\end{array}$ & $\begin{array}{l}\text { Ratio of the landmarks } \\
\text { for the total\% }\end{array}$ \\
\hline Mevlana Museum/Tomb & 1 & 100 & 100 & 100 & 100 \\
\hline Karatay Museum/Medrasa & 2 & 81 & 90 & 73 & 82 \\
\hline Sultan Selim Mosque & 3 & 84 & 90 & 75 & 81 \\
\hline Zafer Square & 5 & 78 & 75 & 75 & 76 \\
\hline Bus Terminal & 6 & 69 & 75 & 72 & 72 \\
\hline Kule Site & 7 & 57 & 60 & 90 & 69 \\
\hline Anit Square & 8 & 24 & 69 & 60 & 51 \\
\hline Dedeman Hotel & 11 & 51 & 45 & 36 & 44 \\
\hline Fair & 12 & 15 & 63 & 45 & 41 \\
\hline Revenue and Municipality Building & 13 & 20 & 5 & 80 & 35 \\
\hline Kibrit Corner & 14 & 27 & 0 & 75 & 34 \\
\hline Aziziye Mosque & 15 & 6 & 30 & 60 & 32 \\
\hline Mc Donalds & 16 & 15 & 25 & 27 & 22 \\
\hline Sille Subway & 17 & 9 & 0 & 51 & 20 \\
\hline Şefik Can & 23 & 3 & 0 & 24 & 9 \\
\hline Konya High School & 24 & 18 & 39 & 9 & 6 \\
\hline Petek Pastanesi & 25 & 9 & 0 & 9 & 6 \\
\hline
\end{tabular}

\section{Results}

Landmark can be a good sign for urban spaces in the cities. Landmark as a word is used in different fields with referring different concept. Sometimes we cannot recognize the city when the perception changes. The same city represents and being as it is but the way of presentation of it totally defines different images. Landmarks, references that become signals, are one of the parts of the communicative way of the city with people. Landmarks are defined as an external point of reference that helps orienting in a familiar or an unfamiliar environment. The issue of this study is to understand how citizens or city users are communicating with the urban space. In this study the relation 
Table 3. The impression about the landmark.

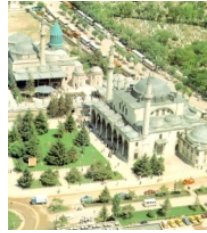

Mevlana Museum/Tomb

Sultan Selim Mosque
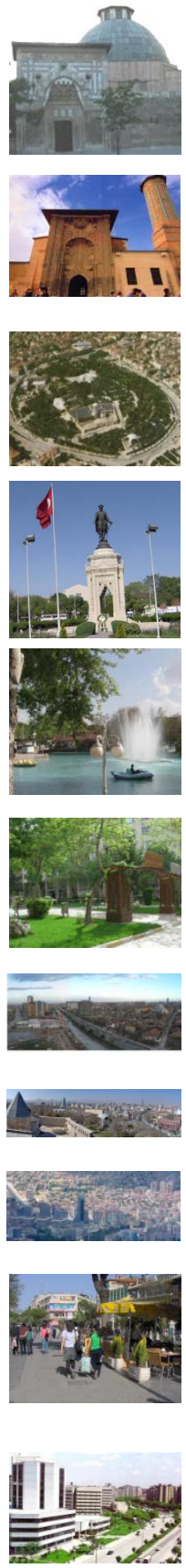

Anit Square

Karatay Museum/Medrasa

İnce Minare

Museum/Medrasa

Alaeddin Hill

Fair

Nene Hatun Park

Dedeman Hotel

Rixos Hotel

Kule Site

Zafer Square

Revenue and Municipality Building
Tourist from Argentine, female, banker, 51 years old

"Konya is the land of Mevlana. Mevlana, who thought that everything rotates in the universe, invited mankind to the devotion of God, hope, love and peace by whirling himself around. This green cone reminds and sembolize all these properties of Sufism and Sultan Selim mosque is defining a square with the Mevlana Tomb."

Tourist from Bulgaria, male, art historian, 57 years old

"Konya is the capital of Ancient Selcuk's. Karatay and İnce Minare is one of the magnificent examples of them. I selected that buildings for the photo because that is why I am here."

City dweller, male, teacher, 37 years old

"Hill of Alaaddin is the my reference point while driving or walking. I think it is not today but also in the past. Since Konya is a flat area, people needed an area safe and in early times the hill allowed the chance to observe the surrounding area for a sudden attack."

Fourth year architecture student, living in Konya 21 years

"We had gathered in Anit Square for the national ceremonies when we were child. This square has an image of solemn image in the citizen mind. Anit Square an intersection well-known by the citizens."

City dweller, male, seller, 47 years old

"My business is very close to that place. I have come that green area often to eat lunch, especially delicious chicken. Fair area was full of idle facilities five years ago. Municipality organized the area as a recreation of the citizens. Now this is a place of call."

City dweller, female, housewife, 67 years old

"I am an old woman. All my life goes on in this park and around nowadays. We chat with my friends, sometimes walk all together in this park. Actually a lot of density and noise around the park."

\section{Landmark as High Rise/Skyscraper}

City dweller, male, advertisers, 25 years old

"In the city there are three tall buildings which affect the city silhouette. You can see this building from all points of the city. You can orient yourself according to those buildings. If you lost your way, you can understand where you are by following these skyscrapers."

\section{Landmark as Daily Life/City Usage}

City dweller, male, the owner of the restaurant, 36-year-old

"This is an pedestrian area. Especially young people used this area day and night. My restaurant and my house is in Zafer so my life is passing here."

City dweller, female, hairdressing, 29 years old

"We pay our taxes regularly so we come that building regularly, all buses, tramways passes from here. This is an intersection point for the citizen." 
McDonalds

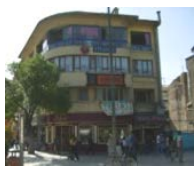

Kibrit Corner

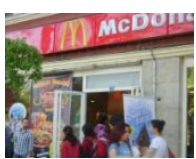

Bus Terminal
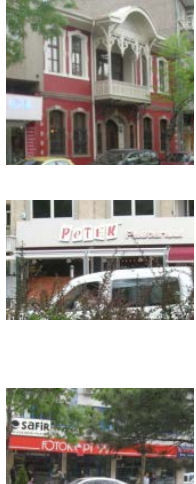

Copy center 99

Chamber of Architecture

Petek Pastanesi

Third year architecture student, living in Konya 5 years

"I do not like Konya as a city so I prefer not to contact or waste time in this city. However I orient myself with Petek Pastery I meet with my girlfriend all the time."

"Sometimes I think that my home is that copy center. Night and day I am with my friend meet at copy center. That is crazy."

\section{Landmark as Circulation Pattern}

Beş Yol (Asıl Ice Cream)

City dweller, male, the state officer, 52 years old

"The outsider may not aware of the importance of that main axis but people living in this city orient themselves according to main streets not only from the map but also from the cognitive

Sille Subway map namely with our experience and memory."

Şefik Can

between semiology of landmarks and urban space based on Konya, Turkey. The method of this study is photo-elicitation to understand how people orient themselves in moving within urban space considering landmarks. Thirty participants took photographs of city center of Konya and interviewed while viewing their photographs. Analysis of interview texts focused on meaning of environment that connected participants to their life style, their perception. When we check the table obtained from photo-elicitation we can get that conclusion;

1) All of the participants (ratio is 100\%) had taken the photo of Mevana Museum/ Tomb as a symbolic and meaningful reference. Museum/Tomb is in the collective memory as a landmark of Konya, even all over the world people heard about Mevlana Celaleddin Rumi so people had a sociologic link between Konya and Mevlana.

2) Karatay Museum/Medrasa, Sultan Selim Mosque, İnce Minare Museum/Medrasa 
is the second landmark group that may be called having historical background and having city memory behind. Almost $80 \%$ people had taken the photo of that Anatolian Selçuk's buildings. Tourists are more conscious about that historical landmark.

3) Zafer Square, Bus Terminal, Kule Site, Anit Square, Rixos Hotel, Alaeddin Hill, Dedeman Hotel, Fair, Revenue and Municipality Building is the third group according to table getting averages more than $50 \%$ per cent of average. This open space (Zafer and Anit square) and the buildings are in the city life. Students and city dwellers are using that spaces often. Thus these places have a meaning for the user and they are a reference point of them.

4) The buildings like Rixos, Dedeman, Kombassan Holding and Kulesite has a semiology for Konya. All groups have found that high-rise buildings which effects the city silhouette.

5) The last group of landmarks is averages almost $14 \%$ of averages. When we look at the phtoes of participant in that group with their story about that photo, we can say that reference point is just a sign in their mind and memory. Kibrit corner, Sille Subway, Şefik Can Street, Beş Yol (Asıl Ice Cream), Nene Hatun Park is well known for the city dweller, on the hand for the tourists that places are not recognizable, or have any meaning. Similarly Copy center 99 and Chamber of Architecture is a sign and have a meaning symbolically. However, tourists and city dwellers have no idea about that specific point.

People choose spontaneously or officially the points in the city to facilitate their orientation. In the city same natural or man-made elements is seen as signs giving the sense of way finding. In this study the semiology of communication studies codes established by society to produce messages consciously sent and received as signals, signs and symbols. A signal or a symbol without doing so on purpose cannot be send. As a last word, landmarks are references that become signals of urban space.

\section{References}

Appleyard, D. (1969). Why Buildings Are Known. Environment and Behavior, 1, 131-156. http://dx.doi.org/10.1177/001391656900100202

Appleyard, D., Lynch, K., \& Randolph, J. (1966). The View from the Road. Cambridge, MA: Massachusetts Institute of Technology.

Bala Alkan, H. (2013). The Semiology of Landmarks in Urban Space. In G. T. Papanikos (Ed.), 3rd Annual International Conference on Architecture (p. 29). Athens: The Athens Institute for Education and Research. http://www.atiner.gr/abstracts/2013ABST-ARC.pdf

Barthes, R., Lavers, A., \& Smith, C. (1967). Writing Degree Zero. London: Jonathan Cape.

Beck, R. J., \& Wood, D. (1976). Cognitive Transformation from Urban Geographic Fields to Mental Maps. Environment and Behavior, 8, 199-238. http://dx.doi.org/10.1177/001391657682003

Caduff, D., \& Timpf, S. (2008). On The Assessment of Landmark Salience for Human Navigation. Cognitive Processing, 9, 249-267. http://dx.doi.org/10.1007/s10339-007-0199-2

Carr, S., \& Schissler, D. (1969). The City as a Trip: Perceptual Selection and Memory in the View from the Road. Environment and Behavior, 1, 7-35. 
http://dx.doi.org/10.1177/001391656900100102

Cornell, E. H., Heth, C. D., \& Skoczylas, M. J. (1999). The Nature and Use of Route Expectancies Following Incidental Learning. Journal of Environmental Psychology, 19, 209-229. http://dx.doi.org/10.1006/jevp.1999.0136

Cubukcu, E., \& Nasar, J. L. (2005). Relation of Physical Form to Spatial Knowledge in Large Scale Virtual Environments. Environment and Behavior, 37, 397-417. http://dx.doi.org/10.1177/0013916504269748

De Saussure, Ferdinand. (1966). Course in General Linguistics (Edited by Charles Bally and Albert Sechehaye, Translated by Wade Baskin). New York, Toronto, London: McGraw-Hill Book Company.

Denis, M. (1997). The Description of Routes: A Cognitive Approach to the Production of Spatial Discourse. Current Psychology of Cognition, 16, 409-458.

Derrida, J. (1978). Writing and Difference (Trans. Alan Bass). Chicago, IL: University of Chicago Press.

Foltête, J. C., \& Prombini, A. (2007). Urban Layout, Landscape Features and Pedestrian Usage. Landscape and Urban Planning, 81, 225-234. http://dx.doi.org/10.1016/j.landurbplan.2006.12.001

Froment, J., \& Domon, G. (2006). Viewer Appreciation of Highway Landscapes: The Contribution of Ecologically Managed Embankments in Quebec, Canada. Landscape and Urban Planning, 78, 14-32. http://dx.doi.org/10.1016/j.landurbplan.2005.05.004

Golledge, R. G. (1991). Cognition of Physical and Built Environments. In T. Garling, \& G. W. Evans (Eds.), Environment, Cognition, and Action (pp. 35-63). New York: Oxford University Press.

Golledge, R. G., \& Stimson, R. J. (1997). Spatial Behavior: A Geographic Perspective. New York: The Guilford Press.

Guiraud, P. (1975). Semiology.

Günay, B. (2005). Skyframe (Gökkafes) in Istanbul: An Ontological Assessment. Journal of Urban Design, 10, 111-132. http://dx.doi.org/10.1080/13574800500062403

Heidegger, M. (1977). Sein und Zeit. In F.-W. Von Herrmann (Ed.), Gesamtausgabe (Vol. 2, Xiv, 586 p). World Heritage Encyclopedia.

Herzog, T. R., \& Kropscott, L. (2004). Legibility, Mystery, and Visual Access as Predictors of Preference and Perceived Danger in Forest Settings without Pathways. Environment and Behavior, 36, 659-677. http://dx.doi.org/10.1177/0013916504264138

Herzog, T. R., \& Leverich, O. L. (2003). Searching for Legibility. Environment and Behavior, 35, 459-477. http://dx.doi.org/10.1177/0013916503035004001

Heth, C. D., Cornell, E. H., \& Alberts, D. M. (1997). Differential Use of Landmarks by 8- and 12-Year-Old Children during Route Reversal Navigation. Journal of Environmental Psychology, 17, 199-213. http://dx.doi.org/10.1006/jevp.1997.0057

Jansen-Osmann, P., \& Wiedenbauer, G. (2004). The Representation of Landmarks and Routes in Children and Adults: A Study in a Virtual Environment. Journal of Environmental Psychology, 24, 347-357. http://dx.doi.org/10.1016/j.jenvp.2004.08.003

Kalin, A., \& Yllmaz, D. (2012). A Study on Visibility Analysis of Urban Landmarks: The Case of Hagia Sophia (Ayasofya) in Trabzon. METU Journal of the Faculty of Architecture, 29, 241-271.

Klippel, A., \& Winter S. (2005). Structural Salience of Landmarks for Route Directions. In A. G. Cohn, \& D. M. Mark (Eds.), Spatial Information Theory (pp. 347-362). Berlin: Springer. http://dx.doi.org/10.1007/11556114 22 
Kravchenko, A. (2006). Cognitive Linguistic Biology of Cognition and Biosemiotics: Bridging the Gaps. Language Sciences, 28, 51-75. http://dx.doi.org/10.1016/j.langsci.2005.02.002

Kuipers, B. (1982). The "Map in the Head" Metaphor. Environment and Behavior, 14, 202-220. http://dx.doi.org/10.1177/0013916584142005

Loomis, J. M., Klatzky, R. L., Golledge, R. G., Cicinelli, J. G., Pellegrion, J. W., \& Fry, P. A. (1993). Nonvisual Navigation by Blindand Sighted: Assessment of Path Integration Ability. Journal of Experimental Psychology: General, 122, 73-91. http://dx.doi.org/10.1037/0096-3445.122.1.73

Lynch, K. (1960). The Image of the City. Cambridge, MA: The MIT Press.

Mankus, M. (2014). Manifestations of Symbolism in Architecture of Postmodernism. Journal of Architecture and Urbanism, 38, 274-282. http://dx.doi.org/10.3846/20297955.2014.998853

May, A. J., \& Ross, T. (2006). Presence and Quality of Navigational Landmarks: Effect on Driver Performance and Implications for Design. Human Factors, 48, 346-361. http://dx.doi.org/10.1518/001872006777724453

Merriman, P. (2004). Driving Places: Marc Augé, Non-Places, and the Geographies of England's M1 Motorway. Theory, Culture \& Society, 21, 145-167.

Morris, C. (1964). Foundations of the Theory of Signs. Toronto: The University of Toronto.

Mounin, G. et al. (1980). The Semiology of Orientation in Urban Space [and Comments and Reply]. Current Anthropology, 21, 491-501. http://dx.doi.org/10.1086/202498

Murrieta-Cid, R., Parra, C., \& Devy, M. (2002). Visual Navigation in Natural Environments: From Range and Color Data to a Landmark-Based Model. Autonomous Robots, 13, 143-168. http://dx.doi.org/10.1023/A:1019685425452

Newcombe, N. S., \& Huttenlocher, J. (2000). Making Space. Cambridge, MA: The MIT Press.

Nikolov, N. (2008). Cinemarchitecture: Explorations into the Scopic Regime of Architecture. Journal of Architectural Education, 62, 41-45. http://dx.doi.org/10.1111/j.1531-314X.2008.00214.x

Omer, I., \& Goldblatt, R. (2007). The Implications of Inter-Visibility between Landmarks on Wayfinding Performance: An Investigation Using a Virtual Urban Environment. Computers, Environment and Urban Systems, 31, 520-534. http://dx.doi.org/10.1016/j.compenvurbsys.2007.08.004

Osborne, B. (2001). Landscapes, Memory, Monuments, and Commemoration: Putting Identity in Its Place. Commissioned by the Department of Canadian Heritage for the Ethnocultural, Racial, Religious, and Linguistic Diversity and Identity Seminar, Halifax, Nova Scotia, 1-2 November 2001. www.metropolis.net

Peebles, D., Davies, C., \& Mora, R. (2007). Effects of Geometry, Landmarks and Orientation Strategies in the "Drop-Off" Orientation Task. In S. Winter, et al. (Eds.), Lecture Notes in Computer Science (Vol. 4736, pp. 390-405).

Peirce, C.S. (1958) Collected Papers of Charles Sanders Peirce. Vols. 1-6, C. Hartshorne, \& P. Weiss (Eds.), Vols. 7-8, A.W. Burks (Ed.), Cambridge, MA: Harvard University Press, pp. 1931-1935.

Presson, C., \& Montello, D. (1988). Points of Reference in Spatial Cognition: Stalking the Elusive Landmark. British Journal of Developmental Psychology, 6, 378-381.

http://dx.doi.org/10.1111/j.2044-835X.1988.tb01113.x

Robertson, R. (2007). Visions of Urban Mobility: The Westway, London, England. Cultural Geographies, 14, 74-91. Visibility Analysis of Urban Landmarks Metu Jfa 2012/1 269 http://dx.doi.org/10.1177/1474474007072820

Roger, M., Bonnardel, N., \& Le Bigot, L. (2009). Improving Navigation Messages for Mobile Ur- 
ban Guides: Effects of The Guide's Interlocutor Model, Spatial Abilities and Use of Landmarks on Route Description. International Journal of Industrial Ergonomics, 39, 509-515.

http://dx.doi.org/10.1016/j.ergon.2008.10.009

Rossano, M. J., West, S. O., Robertson, T. J., Wayne, M. C., \& Chase, R. B. (1999) The Acquisition of Route and Survey Knowledge from Computer Models. Journal of Environmental Psychology, 19, 101-115.

Sadalla, E. K., Burroughs, W. J., \& Staplin, L. J. (1980). Reference Points in Spatial Cognition. Journal of Experimental Psychology: Human Learning and Memory, 6, 516-528. http://dx.doi.org/10.1037/0278-7393.6.5.516

Stewart, W. P., Derek, W., \& Larkin, K. W. (2004). Community Identities as Visions for Landspace Change. Landscape and Urban Planning, 69, 315-334.

http://dx.doi.org/10.1016/j.landurbplan.2003.07.005

Taylor, N. (2003) The Aesthetic Experience of Traffic in the Modern City. Urban Studies, 40, 1609-1625. http://dx.doi.org/10.1080/0042098032000094450

Zacharias, J. (2001) Pedestrian Behavior and Perception in Urban Walking Environments. Journal of Planning Literature, 16, 3-18. http://dx.doi.org/10.1177/08854120122093249

Zappulla, C., Suau, C., \& Fikfak, A. (2014). The Pattern Making of Megaslums on Semantics in Slum Urban Cultures. Journal of Architecture and Urbanism, 38, 247-264. http://dx.doi.org/10.3846/20297955.2014.987368

Submit or recommend next manuscript to SCIRP and we will provide best service for you:

Accepting pre-submission inquiries through Email, Facebook, LinkedIn, Twitter, etc.

A wide selection of journals (inclusive of 9 subjects, more than 200 journals)

Providing 24-hour high-quality service

User-friendly online submission system

Fair and swift peer-review system

Efficient typesetting and proofreading procedure

Display of the result of downloads and visits, as well as the number of cited articles

Maximum dissemination of your research work

Submit your manuscript at: http://papersubmission.scirp.org/

Or contactcus@scirp.org 